\title{
In Vitro Preservation of Higo Chrysanthemum (Dendranthema $\times$ grandiflorum (Ramat.) Kitam.)
}

\author{
Nyoyen J. L. Roxas, Yosuke Tashiro, Sadami Miyazaki, Shiro Isshiki and Akito Takeshita \\ Faculty of Agriculture, Saga University, Saga 840
}

\begin{abstract}
Summary
In order to establish a method for the preservation of Higo chrysanthemum cultivars (Dendranthema $\times$ grandiflorum (Ramat.) Kitam.), studies were conducted on the influences of the type of explant, temperature, light and other conditions on the survival and growth of cultures in vitro.

Cultures at $5{ }^{\circ} \mathrm{C}, 15^{\circ} \mathrm{C}, 25^{\circ} \mathrm{C}$ and $25^{\circ}-15^{\circ}-5^{\circ} \mathrm{C}$ had maximum rates of $100 \%, 60 \%$, $53 \%$ and $100 \%$ of survival, respectively, for a period of 12 months. Cultures at $15{ }^{\circ} \mathrm{C}$ and $25^{\circ} \mathrm{C}$ showed a comparatively active growth and advanced senescence or withering after 12 months of incubation. On the other hand, cultures at $5{ }^{\circ} \mathrm{C}$ and $25^{\circ}-15^{\circ}-5^{\circ} \mathrm{C}$ showed growth retardation and delayed senescence which had maximum rates of $100 \%$ and $75 \%$ survival, respectively after 24 months. Dark condition increased the survival rate of cultures at $5{ }^{\circ} \mathrm{C}$ although the plant height was comparatively smaller than that under light. Nodal segments showed higher survival rate than the apical buds, and the removal of the expanded leaf on the explant showed advantages upon incubation. One $\mathrm{ml}$ of MS medium without growth regulators in a $12 \times 75 \mathrm{~mm}$ test tube was enough to ensure the survival of a culture at $5{ }^{\circ} \mathrm{C}$ for a period of 24 months without transferring to a new medium or without supplementing the medium.

Based on the above results, a practically safe, economical and useful system for the in vitro preservation of Higo chrysanthemum has been established. This is presently applied to the 21 cultivars.
\end{abstract}

\section{Introduction}

Higo chrysanthemum (Dendranthema $\times$ grandiflorum (Ramat.) Kitam.), Higo-giku in Japanese, is a unique group of chrysanthemum cultivars which has been exclusively cultivated in Higo (the old name of Kumamoto Prefecture) of Kyushu island for more than 2 centuries. This group of cultivars is unique in the sense that inflorescences which comprise different shapes (flat, tubular, spoonlike), sizes (small, medium, large) and colors (red, yellow, white) are still arranged in the strictly prescribed manner, originally established by the Hideshima school during the latter part of the 17 th century (Murayama, 1974). Besides being a part of Japanese traditional horticulture, these cultivars are potential genetic resources for the improvement of modern chrysanthemums. Since these cultivars are continuously propagated in the field,

Received for publication 21 July 1994. there is a high possibility that they may vanish due to their susceptibility to disease or may set seeds that would lead to cultivar contamination by the seedlings. It is worthwhile and necessary to establish a safe and convenient method for the preservation of these valuable cultivars.

Considerable interest has been generated in exploring the storage methods of the chrysanthemums through cryopreservation (Bannier and Steponkus, 1972; Fukai, 1990, 1992; Fukai et al., 1991), low temperature preservation (Fukai et al., 1988; Fukai and Oe, 1989), and room temperature preservation (Hosoki, 1989). In cryopreservation, the risk of genetic changes due to the callus formation or destruction of chimera structure prior to regeneration of shoots are to be considered. In the case of low and room temperature preservations, culture conditions such as appropriate temperature and light conditions, explant, medium, growth regulator, volume of medium, vessel, control of contamination and protection from desiccation still 
remain to be improved.

The objectives of the present study were to investigate the influences of (1) temperature, (2) light, and (3) type of explant on the survival rate and growth of cultures in vitro.

\section{Materials and Methods}

Hormone-free MS medium (Murashige and Skoog, 1962) containing $2 \%$ sucrose and $0.8 \%$ agar was used in this study. The $\mathrm{pH}$ of the media was adjusted to 5.7 before autoclaving at $121{ }^{\circ} \mathrm{C}$ for $15 \mathrm{~min}$ and was distributed in polystyrene test tubes $(12 \times 75 \mathrm{~mm})$ at $1 \mathrm{ml}$ per tube. Apical buds and nodal segments (node Nos. 3 and 5, the node count starting from the first expanded leaf blade of the plant), with and without leaf blades, were excised from a 3 -month old in vitro grown plantlets of Higo chrysanthemum, cv. Horen and were plated onto the media. The test tubes were placed in test tube racks, packed in a transparent plastic container (Sanplatec 2258AO, 270 × $205 \times 96$ $\mathrm{mm}$ ) sealed with insulation tape (Fig. 1). Cultures were placed under light and dark at $5{ }^{\circ} \mathrm{C}, 15^{\circ} \mathrm{C}$, $25^{\circ} \mathrm{C}$ and $25^{\circ}-15^{\circ}-5^{\circ} \mathrm{C}$. At the last temperature condition, the cultures were placed at $25^{\circ} \mathrm{C}$ and $15{ }^{\circ} \mathrm{C}$ for 10 days each and then at $5{ }^{\circ} \mathrm{C}$. Cultures under ligth were exposed to $16 \mathrm{hr}$ light (fluorescent light, $2500 \mathrm{~lx}$ measured at the center of the container) and $8 \mathrm{hr}$ darkness, while cultures under dark conditions were wrapped with aluminum foil. Evaluation of survival rate and growth were made 6,12 and 24 months after inoculation. For the evaluation of growth, only alive cultures were considered in plant height, number of leaves, percentage of cultures that rooted and formed axillary shoots.

\section{Results}

\section{Temperature}

On the 6 th month, cultures at $5{ }^{\circ} \mathrm{C}(*)$ showed the highest survival rate among the four temperature conditions used (Fig. 2). There were many cultures that remained alive, but no visible signs of growth, e.g. leaf expansion or internode elongation, were observed at $5{ }^{\circ} \mathrm{C}$ and $25^{\circ}-15^{\circ}-5^{\circ} \mathrm{C}$ under dark conditions. Cultures at $25{ }^{\circ} \mathrm{C}$ were observed to have the highest plant height and number of unfolded leaves among the four temperature conditions (Figs. 3 and 4). Very short internodes were observed in a considerable number of cultures at $15{ }^{\circ} \mathrm{C}$ under light (Fig. 3). Almost all the cultures at $15{ }^{\circ} \mathrm{C}$ and $25^{\circ} \mathrm{C}$ formed roots

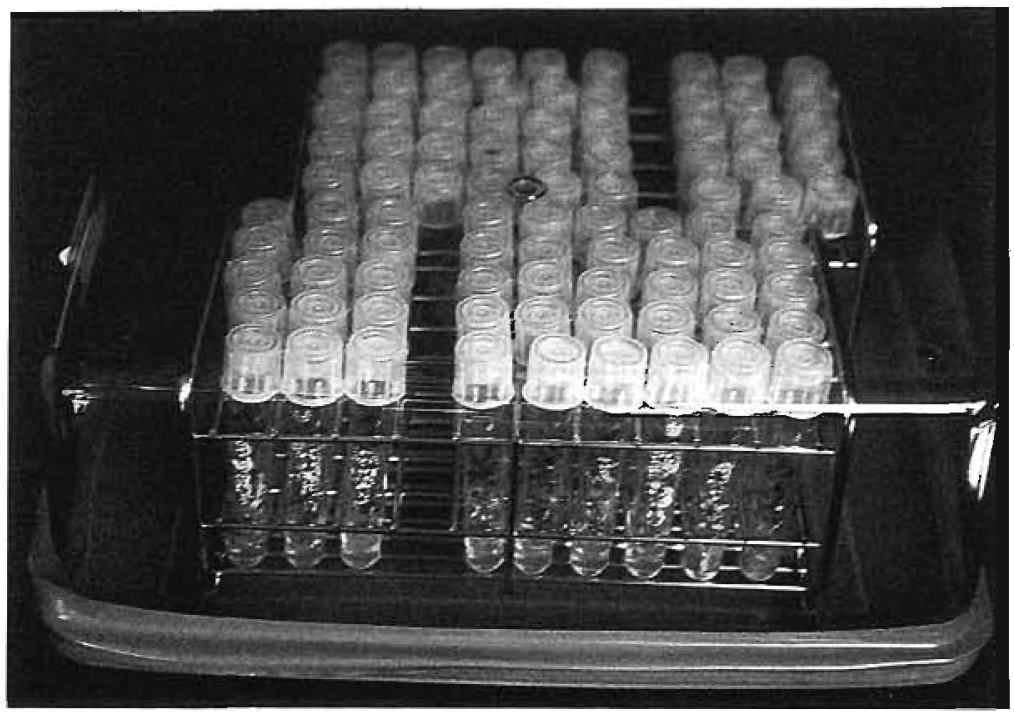

Fig. 1. Cultures of Higo chrysanthemum cv. Horen incubated on $1 \mathrm{ml}$ medium in a $12 \times 75 \mathrm{~mm}$ test tube and packed in a plastic container sealed with an insula tion tape.

\footnotetext{
* When only temperature is specified it includes cultures both under light and dark conditions.
} 

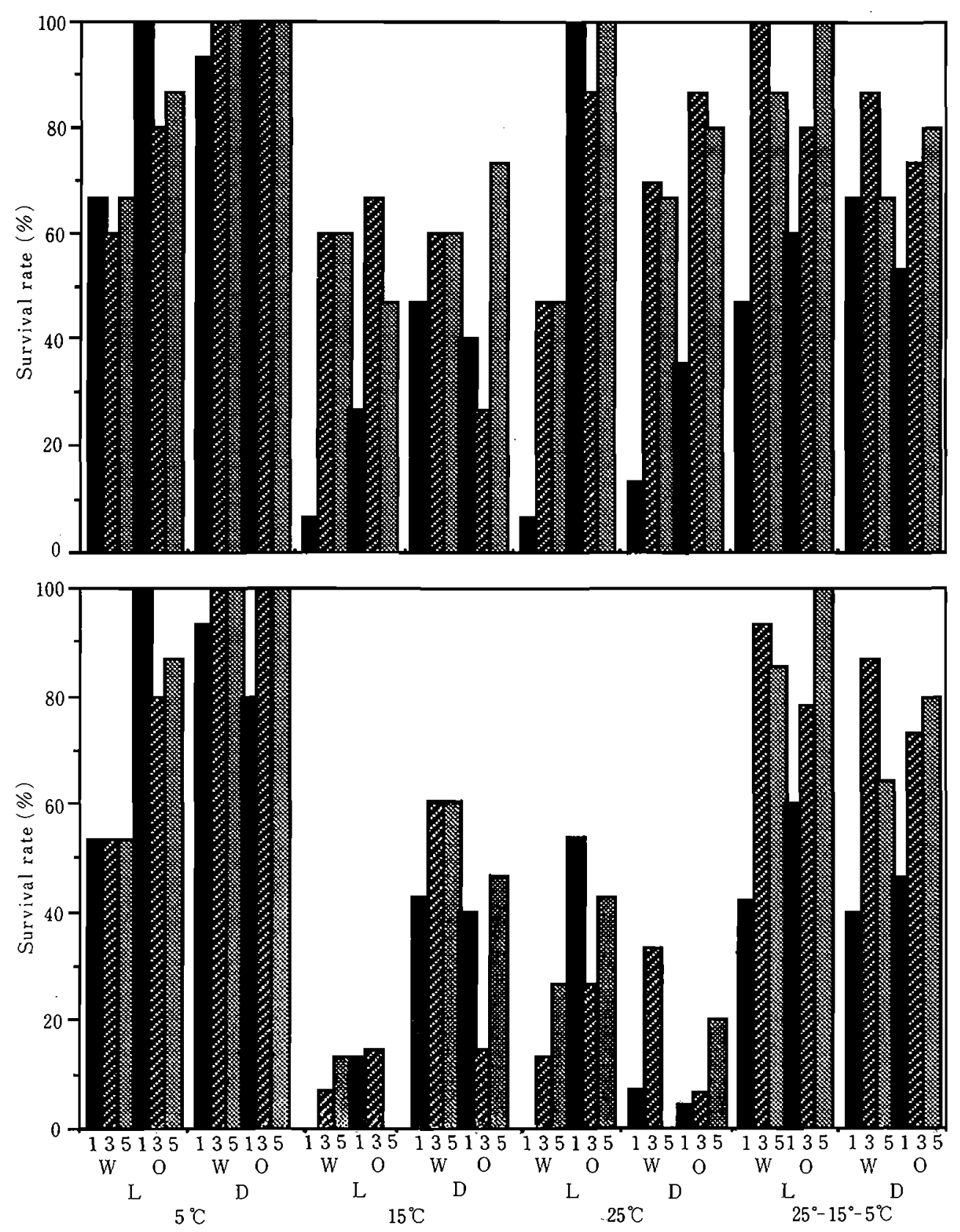

Fig. 2. Survival rate of cultures of Higo chrysanthemum cv. Horen 6 (upper) and 12 months (lower) after inoculation. Apical buds ( 1$)$ and nodal segments $(3,5)$ with $(\mathrm{W})$ and without $(0)$ expanded leaf blades were cultured under light (L) and dark (D) conditions at $5^{\circ} \mathrm{C}, 15^{\circ} \mathrm{C}, 25^{\circ} \mathrm{C}$ and $25^{\circ}-15^{\circ}-5^{\circ} \mathrm{C}$.

while a considerable number of cultures at $5{ }^{\circ} \mathrm{C}$ and $25^{\circ} \cdot 15^{\circ}-5{ }^{\circ} \mathrm{C}$ were found to develop no root (Fig. 4). Axillary shoot formations were only observed in a limited number of cultures at $15{ }^{\circ} \mathrm{C}$ and $25{ }^{\circ} \mathrm{C}$ under light.

After 12 months of culture, survival rate drasti- 


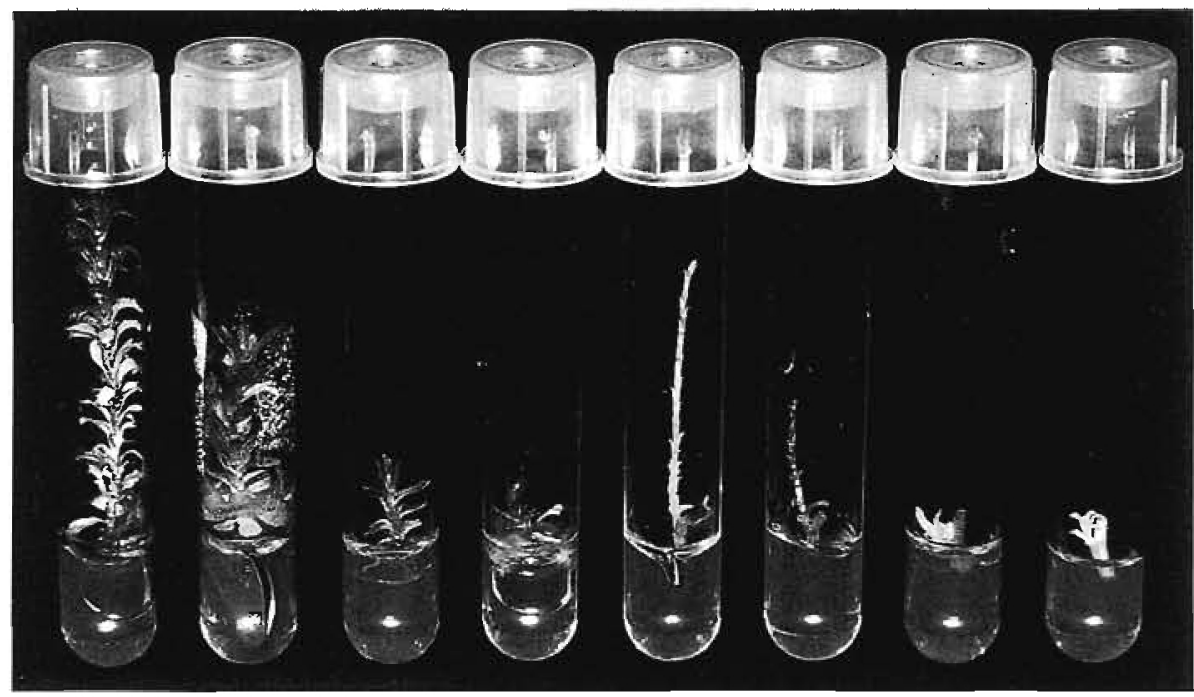

Fig. 3. Cultures of Higo chrysanthemum cv. Horen incubated at $25^{\circ} \mathrm{C}, 15{ }^{\circ} \mathrm{C}, 5{ }^{\circ} \mathrm{C}$ and $25^{\circ}-15^{\circ}-5$ ${ }^{\circ} \mathrm{C}$ under light (first 4 test tubes from the left) and dark (last 4 test tubes in the same sequence) conditions 6 months after inoculation.

cally decreased in the cultures at $15{ }^{\circ} \mathrm{C}$ under light and $25^{\circ} \mathrm{C}$, while a slight decrease in the rate was observed in cultures at $5{ }^{\circ} \mathrm{C}, 15^{\circ} \mathrm{C}$ under dark conditions and $25^{\circ}-15^{\circ}-5^{\circ} \mathrm{C}$ (Fig. 2). Plant height of cultures at $15{ }^{\circ} \mathrm{C}$ under dark condition showed considerable increase, while a slight in. crease was observed in those at $5{ }^{\circ} \mathrm{C}$ and $25^{\circ}-15^{\circ}$. $5{ }^{\circ} \mathrm{C}$ (Figs. 4 and 5). On the other hand, it was difficult to detect the exact details of plant growth at $15{ }^{\circ} \mathrm{C}$ under light and $25{ }^{\circ} \mathrm{C}$ because they rapidly outgrew the culture vessel and many did not survive for a year. An enhanced root formation was clearly observed on cultures at $5{ }^{\circ} \mathrm{C}$ under light conditon. Some cultures at $15{ }^{\circ} \mathrm{C}$ and $25{ }^{\circ} \mathrm{C}$ showed axillary shoot formation, while none was observed at $5{ }^{\circ} \mathrm{C}$ and $25^{\circ}-15^{\circ}-5^{\circ} \mathrm{C}$.

After 24 months of incubation, survival rate fairly decreased at both $5{ }^{\circ} \mathrm{C}$ and $25^{\circ}-15^{\circ}-5{ }^{\circ} \mathrm{C}$ (Fig. 6). The plant height of the cultures considerably increased at $5{ }^{\circ} \mathrm{C}$ and $25^{\circ}-15^{\circ}-5{ }^{\circ} \mathrm{C}$ under light while a moderate increase was observed in the cultures at $5{ }^{\circ} \mathrm{C}$ and $25^{\circ}-15^{\circ}-5^{\circ} \mathrm{C}$ under dark conditions (Fig. 7). The accurate plant height under light in both temperatures could not be determined since the upper portion of some plantlets tended to wind $3 \sim 4$ times upon reaching the top of the test tube. There was no obvious difference in root formation under both temperature condi. tions between the 12th and 24th months of observations. Consequently, no considerable difference was observed in the survival rates and growth between cultures at $5^{\circ} \mathrm{C}$ and $25^{\circ}-15^{\circ}-5^{\circ} \mathrm{C}$.

Light

Cultures under light showed green leaves and yellow-green stems, while etiolated stems and scale-like leaves were observed in the cultures under dark conditions (Figs. 3,5 and 7 ). The etiolated cultures maintained the capability of chlorophyll synthesis for 2 years when transferred to standard proliferation conditions $\left(25{ }^{\circ} \mathrm{C}\right.$ under light). In the case of cultures at $5{ }^{\circ} \mathrm{C}$ under dark conditions, the survival rate was higher than that under light after 6,12 , and 24 months of incubation (Figs, 2 and 6). Cultures at $5{ }^{\circ} \mathrm{C}$ and $25^{\circ}$. $15^{\circ} .5{ }^{\circ} \mathrm{C}$ both under light showed higher plant height than cultures under dark conditions. On the 12 th month, however, cultures at $15{ }^{\circ} \mathrm{C}$ under dark conditions showed significantly higher survival rate and plant height than those at $15{ }^{\circ} \mathrm{C}$ under light. Root formation was more frequent in the cultures under light than those under dark conditions in all the temperatures studied (Fig. 4).

\section{Apical bud vs, nodal segments}

Apical buds generally showed lower survival 

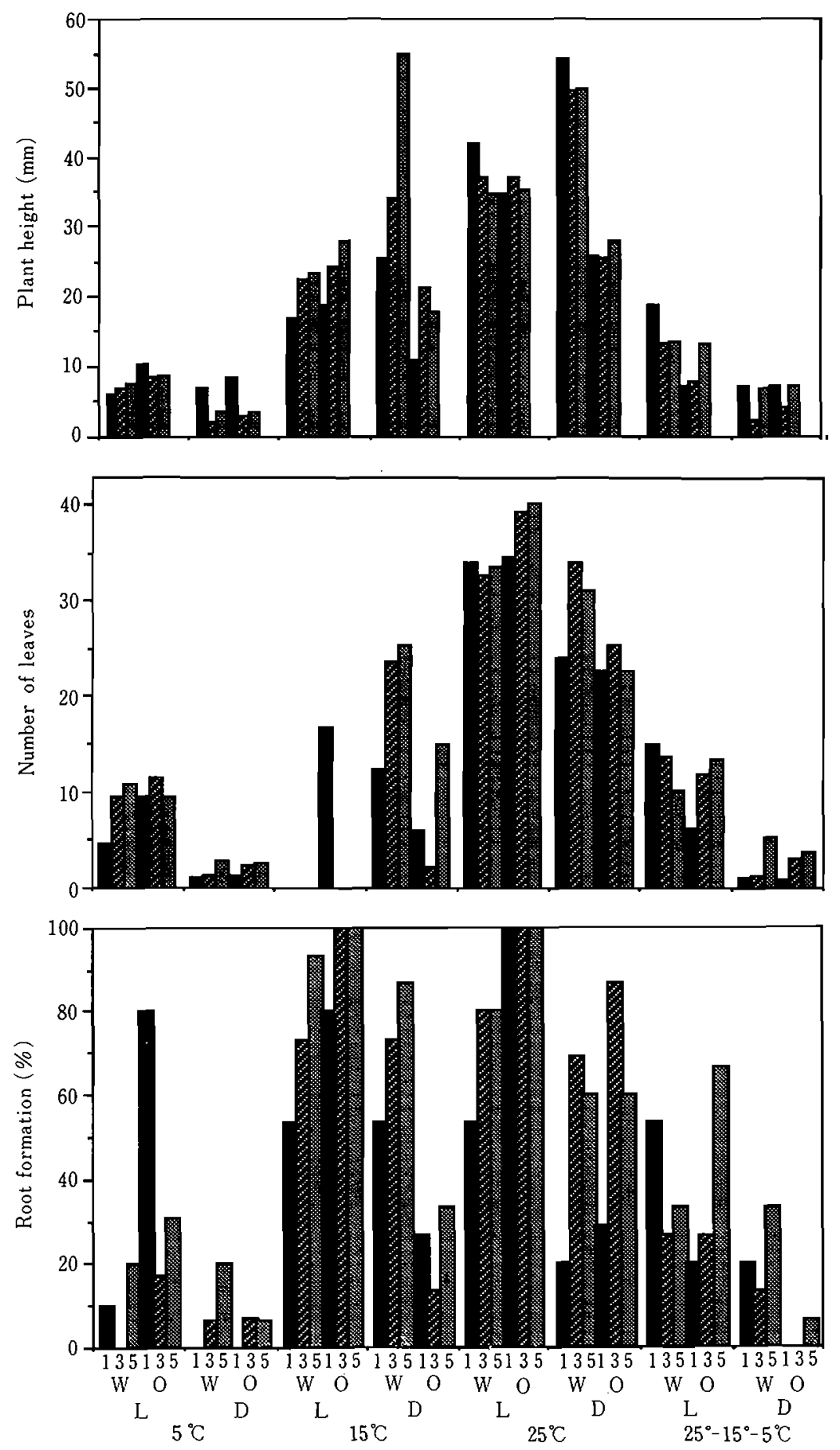

Fig. 4. Plant height (upper), number of leaves (middle), and root formation (lower) of cultures of Higo chrysanthemum cv. Horen 6 months after inoculation. Symbols used are the same as in Fig. 2. 


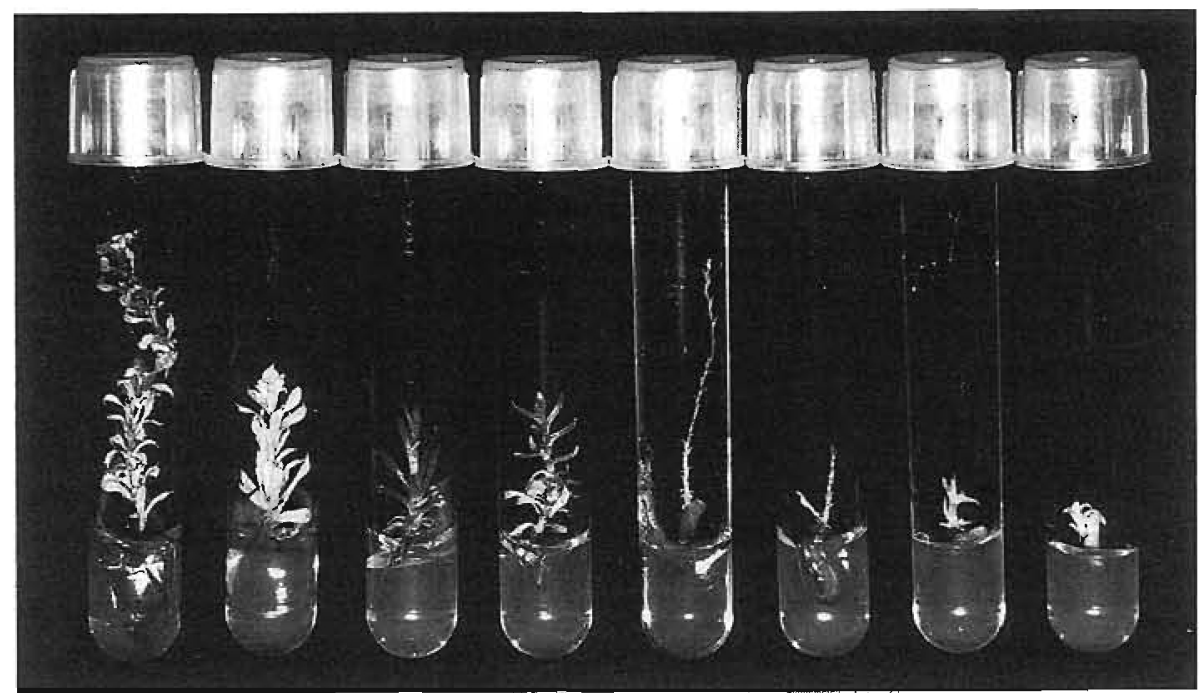

Fig. 5. Cultures of Higo chrysanthemum cv. Horen incubated at $25^{\circ} \mathrm{C}, 15{ }^{\circ} \mathrm{C}, 5{ }^{\circ} \mathrm{C}$ and $25^{\circ}-15^{\circ}-5$ ${ }^{\circ} \mathrm{C}$ under light (first 4 test tubes from the left) and dark (last 4 test tubes in the same sequence) conditions 12 months after inoculation.

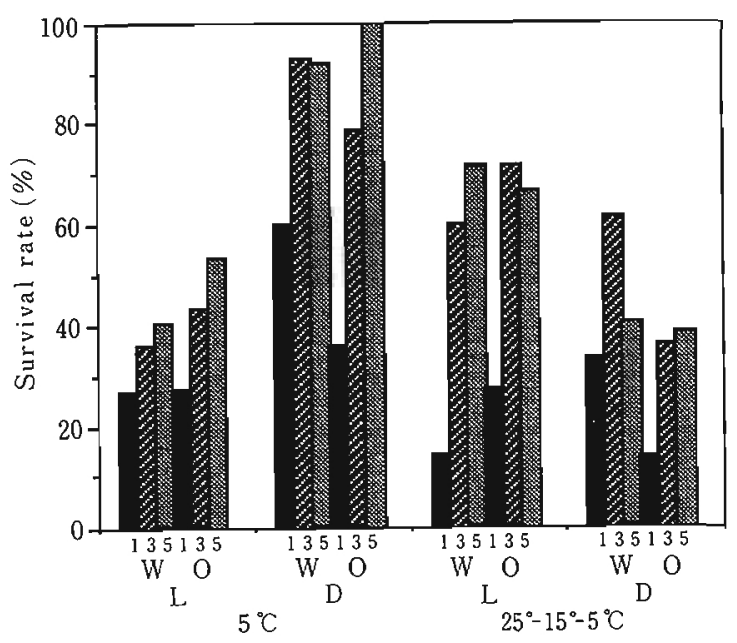

Fig. 6. Survival rate of cultures of Higo chrysanthemum cv. Horen 24 months after inoculation. Symbols used are the same as in Fig. 2.

rate than nodal segments. However, in the cultures at $5{ }^{\circ} \mathrm{C}$ during 6 and 12 months of observations no significant differences were seen among the apical buds and nodal segments Nos. 3 and 5 (Figs. 2 and 6).

\section{Expanded leaf blades}

Presence or absence of expanded leaf on the ex-

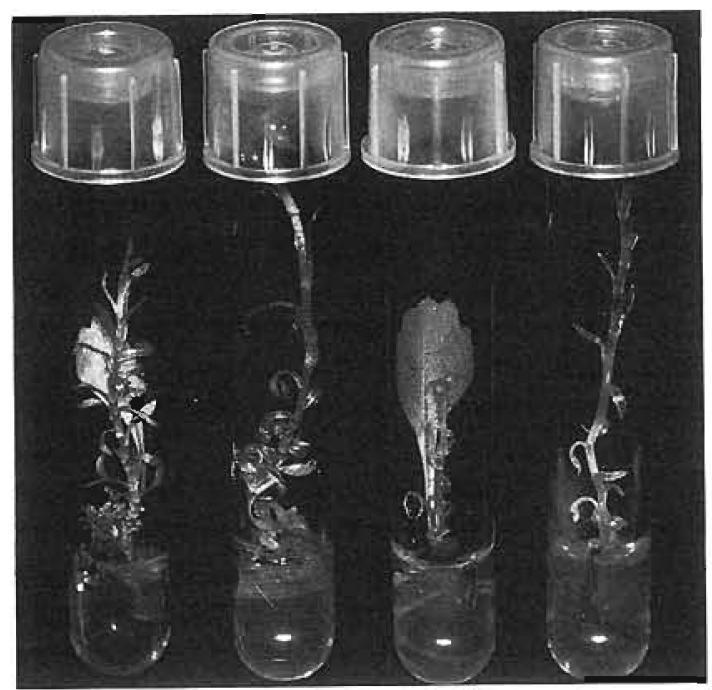

Fig. 7. Cultures (with and without expanded leaf blade) of Higo chrysanthemum cv. Horen incubated under light at $5{ }^{\circ} \mathrm{C}$ (first 2 test tubes from the left) and dark (last two test tubes in the same sequence) conditions 24 months after inoculation.

plants showed no influence on the survival rate, plant height, and root formation (Figs. 2, 4 and 6). However, when expanded leaf blade touched the wall of the test tube, the explant was lifted and was forced to get into the medium or turned 
upside-down which prevented the normal contact with the medium (data not shown).

\section{Other observation}

A volume of $1 \mathrm{ml}$ MS medium without growth regulators in a $12 \times 75 \mathrm{~mm}$ test tube ensured the survival of a culture without transferring to a new medium or supplementing the medium for a period of 24 months in cultures at $5{ }^{\circ} \mathrm{C}$ and $25^{\circ}-15^{\circ}-5^{\circ} \mathrm{C}$ and 12 months in cultures at $15{ }^{\circ} \mathrm{C}$ and $25^{\circ} \mathrm{C}$. The size of the test tube was too small for the explant with expanded leaf blade but it was enough for the explant without expanded leaf blade. A slight desiccation was observed in cultures at $15^{\circ} \mathrm{C}$ and $25^{\circ} \mathrm{C}$ only under light on the 6 th month and severe desiccation was observed in those at $15{ }^{\circ} \mathrm{C}$ and $25^{\circ} \mathrm{C}$ on the 12 th month of observation.

\section{Discussion}

Cultures at low temperatures such as $5{ }^{\circ} \mathrm{C}$ and $25^{\circ}-15^{\circ}-5{ }^{\circ} \mathrm{C}$ showed higher survival rate than those at high temperatures of $15^{\circ} \mathrm{C}$ an $25^{\circ} \mathrm{C}$ (Fig. 2 ). Cultures at low temperatures, especially under dark conditions, showed slow shoot elongation, less frequencies of root and axillary shoot formation which may indicate low metabolic activity. Therefore, it is with reason to say that low metabolic activity contributed to the higher survival rate of cultures at low temperature for longer period of in vitro culture.

In this study, it is demonstrated that the maximum survival rates were $100 \%$ at $5{ }^{\circ} \mathrm{C}$ and $71 \%$ at $25^{\circ}-15^{\circ}-5^{\circ} \mathrm{C}$, after 24 months of culture. Furthermore, cultures at $5{ }^{\circ} \mathrm{C}$ have advantages over those at $25^{\circ}-15^{\circ}-5{ }^{\circ} \mathrm{C}$ since the former does not require extra attention and additional facilities for the temperature control. Thus, preculture at $25^{\circ} \mathrm{C}$ and $15{ }^{\circ} \mathrm{C}$ preceding the culture at $5{ }^{\circ} \mathrm{C}$ seems unnecessary in this system. In the cold storage of chrysanthemum shoot tips Fukai and Oe (1989) mentioned that preculture was effective when explants were excised during summer. In their study, explants were directly taken from greenhousegrown plants, while in the present study explants were from aseptically cultured plantlets. In this way, necessity of preculture seems to be influenced by such state of the mother plants. To obtain a stabilized result of in vitro preservation it will be essential to establish the aseptic cultures prior to the inoculation.
Dark condition increased the survival rate of cultures at $5{ }^{\circ} \mathrm{C}$ although plant height was comparatively restricted than that under light which supports the results of Marino et al. (1985) in the in vitro storage of Prumus. It has not been confirmed yet if cultures under dark conditions for over 2 years can maintain the capability of chlorophyll synthesis. In the case of strawberry coldstored for 6 years under dark, regenerated plantlets exhibited normality when transferred to sterilized soil (Mullin and Schlegel, 1976).

In the present system, nodal segments showed higher survival rate than the apical buds. Only one apical bud is available in a single shoot but several nodal segments can be supplied from the same shoot. At this point, the nodal segments seem to surpass the apical bud as explant. Attached expanded leaf blade touched the wall of the test tube and caused the culture to be elevated from the media or made the cultures turned upside-down and eventually caused death. Therefore, it is practical to excise the expanded leaf blade from the explant upon inoculation.

One $\mathrm{ml}$ of MS medium without growth regulators in a $12 \times 75 \mathrm{~mm}$ test tube was enough to ensure the survival of a culture at $5{ }^{\circ} \mathrm{C}$ for a period of 2 years without transferring to a new medium or supplementing the medium. Other treatments such as growth retardants, high osmotic pressure, and low or high concentrations of sucrose which often causes abnormal growth are not necessary in the in vitro preservation of Higo chrysanthemums for a period of 2 years as shown in this study. Previous studies (Hosoki, 1989; Mullin and Schlegel, 1976) met the problems of contamination and desiccation when bare test tubes were used. In this study, all culture tubes were set in air-tight plastic containers. Even though the comparative data were not shown, the containers used in this study are supposed to actually prevent desiccation and contamination of cultures. Another valuable advantage of using these plastic containers is that only surface sterilization of the test tube is necessary at transplanting during sub-culture and micropropagation. The method of micropropagation, establishment of regenerated plantlets to soil and field test for somaclonal variation in Higo chrysanthemum cultivars will be reported separately.

It was demonstrated that in vitro culture was an interesting and convenient method for the pres- 
ervation of the unique cultivars of Higo chrysanthemum. This system is presently applied to the 21 cultivars of Higo chrysanthemum based on the results of the present study. It can be adapted for the preservation of the other cultivars and strains of chrysanthemums and may facilitate germplasm preservation to any other plant species.

\section{Acknowledgement}

The authors are grateful to Drs. Yutaka Takagi and V. V.R. N. Sastry of the Faculty of Agriculture, Saga University for their valuable suggestions.

\section{Literature Cited}

Bannier, L. J. and P. L. Steponkus. 1972. Freeze preservation of callus cultures of Chrysanthemum mori. folium Ramat. HortScience $7: 194$.

Fukai, S. 1990. Cryopreservation of chrysanthemum shoot tips. Scientia Hortic. $45:$ 167-174.

Fukai, S. 1992. Studies on the cryopreservation of shoot tips of Dianthus and Chrysanthemum. Mem. Fac. Agr., Kagawa Univ. 56:1-79.

Fukai, S., M. Goi and M. Tanaka. 1991. Cryopreservation of shoot tips of Chrysanthemum morifolium and related species native to Japan. Euphytica 54
:201-204.

Fukai, S., M. Morii and M. Oe. 1988. Storage of chrysanthemum (Dendranthema grandiflorum (Ramat.) Kitamura). Plantlets in vitro. Plant Tissue Culture Letters $5: 20-25$.

Fukai, S. and M. Oe. 1989. Cold storage of shoot tips of chrysanthemum (Dendranthema grandiflorum (Ramat.) Kitamura). Plant Tissue Culture Letters 6 : 10-13.

Hosoki, T. 1989. In vitro storage of Chrysanthemum morifolium at room temperature. Plant Tissue Culture Letters $6: 85-87$.

Marino. G.. P. Rosati and F. Sagrati. 1985. Storage of in vitro cultures of Prunus rootstocks. Plant Cell Tissue Organ Culture $5: 73-78$.

Mullin, R. H. and D. E. Schlegel. 1976. Cold storage maintenance of strawberry meristem plantlets. HortScience 11: 100-101.

Murayama, F. 1974. Higo-giku bunkashi (The cultural history of Higo chrysanthemum). p. 293-307. In: Higo-meika-hozonkai (ed.). Higo-rokka-sen (Six celebrated flowering plants in Higo): SeibundoShinkosha, Tokyo. (In Japanese).

Murashige, T. and F. Skoog. 1962. A revised medium for rapid growth and bioassay with tobacco tissue cultures. Physiol. Plant. 15 : 473-497.

\title{
肥後ギクの in vitro 保存
}

\author{
Nyoyen J. L. Roxas - 田代洋丞・宮崎貞巳 - 一色司郎 - 竹下昭人 \\ 佐賀大学農学部 840 佐賀市本庄町 1
}

\begin{abstract}
摘 要
約 200 年前から熊本地方で育成・保存されて来た肥 後ギク品種群を in vitroで保存する方法を開発するた めに，肥後ギク培盖物の生存および生長に及ぼす温度， 光およびその他の培盖条件の影響を調査した。

培養温度が培養物の生存に及ぼす影謷は顕著で，培 盖 1 年後の生存率の最大值は $5{ }^{\circ} \mathrm{C}$ 区で $100 \%, 15^{\circ} \mathrm{C}$ 区で $60 \%, 25{ }^{\circ} \mathrm{C}$ 区で $53 \%$ 拈よび $25^{\circ}-15^{\circ}-5{ }^{\circ} \mathrm{C}$ 区

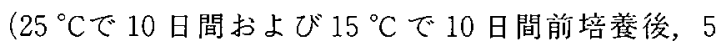

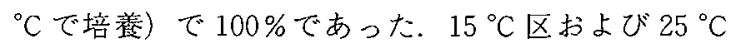
区では培養物の生長が比較的旺盛であり，培盖 1 年後 には老化，褐変あるいは枯死した培養物が多かったが， $5{ }^{\circ} \mathrm{C}$ 区㧍よび $25^{\circ}-15^{\circ}-5{ }^{\circ} \mathrm{C}$ 区では生長が緩慢で，老

化・褐変が遅く, 生存率の最大值は 2 年後でもそれぞ れ 100\%，71\%であった． $5{ }^{\circ} \mathrm{C}$ 区では暗黑下が照明下 より草丈は低かったが, 生存率は高かった。節切片は 頂芽より生存率が高く，節に着生する展開葉の葉身を 切除した方が培養に好都合であった. $12 \times 75 \mathrm{~mm}$ の試 験管に入れた $1 \mathrm{ml}$ のホルモンフリーMS 培地に節切 片を植え付け， $5{ }^{\circ} \mathrm{C}$ で培養すれば， 2 年間は移植ある いは培地の追加をしなくても，培养物の生存が十分に 保証された。

以上の結果から，簡便で安全な肥後ギクの in vitro 保存法を確立することができ, 現在, 21 品種を本法 で保存中である.
\end{abstract}

